\title{
Stink Bug Communication with Multimodal Signals Transmitted through Air and Substrate
}

\author{
Andrej Čokl ${ }^{\text {a* }}$, Alenka Žunič-Kosi ${ }^{\text {a }}$, Raul Alberto Laumann ${ }^{\text {b }}$ \\ ${ }^{a}$ Department of Organisms and Ecosystems Research, National Institute of Biology, Večna pot 111, SI-1000 Ljubljana, Slovenia \\ ${ }^{b}$ Laboratorio de Semioquimicos, Embrapa Recursos Geneticos e Biotecnologia, Avda W5 Norte (Final), 71070, Brasilia, DF, Brazil
}

\begin{abstract}
This review represents complex mechanisms and processes of multimodal communication in stink bugs. During reproductive behavior the airborne and substrate-borne signals enable mate recognition, mediate directionality of movement, eliminate rivals and motivate partners for copulation. Species specific characteristics prevent hybridization at various levels of mating behavior. Male sex and/or aggregation pheromones as uni- or multicomponent signals attract mates to land on the same plant and there, trigger females to call males by vibratory signals, transmitted through the plant. Communication during courtship runs at short distance with visual, airborne, substrate-borne and contact chemical and mechanical signals. Abdomen vibrations produce the main repertoire of female and male calling, courtship and rival vibratory signals. To increase their informational value, stink bugs tune signal frequency, amplitude and temporal characteristics with mechanical properties of plants. The airborne component of species non-specific and high amplitude signals, produced by body tremulation and wing buzzing enables communication contact between mates standing on mechanically isolated plants. Female vibratory signals increase the amount of male emitted pheromone and the latter keeps female calling. Interaction, synergy and characteristics of visual, contact chemical and vibratory signals, exchanged during courtship remain under-investigated. Female and male competition for access to copulation in imbalanced sex conditions is characterized by duetting with rival song vibratory signals. Different receptors in and on different parts of the body are able to detect with high sensitivity multimodal airborne and substrate-borne communication signals. The relevance of the multimodal communication for the reproductive success of stink bugs is discussed.
\end{abstract}

\section{Keywords:}

Insects;

Pentatomidae;

Communication;

Signals;

Multimodality;

Transmission Medium;

Environment.

Article History:

Received: $\quad 10 \quad$ September 2019

Accepted: 21 November 2019

Published: $01 \quad$ December 2019

\section{1- Introduction}

Millions of insect species inhabit air, water and land. Population success depends crucially on efficient communication, which enables solitary species to meet in the field and holds insect societies together. To preserve above-threshold signal-to-noise ratio at the necessary distance, solitary insects developed, through evolution, efficient mechanisms to communicate by unimodal, multimodal and multicomponent signals [1] transmitted through different media. Investigation of insect communication demands a holistic approach to understand the role, synergy and interaction of specific processes underlying different phases of behavior. The study on the wandering spider Cuppienius salei (Keyserlink, 1877) represents a nice example of such an approach, showing the complex system of communication through different channels in various environmental conditions [2]. Comparable studies are rare in insects and, despite numerous solutions and a variety of mechanisms, there are very few common and general conclusions.

Stink bugs (Heteroptera: Pentatomidae: Pentatominae) represent a smaller but economically important group of

\footnotetext{
* CONTACT: Andrej.cokl@ nib.si

DOI: http://dx.doi.org/10.28991/esj-2019-01203
}

(C) 2019 by the authors. Licensee ESJ, Italy. This is an open access article under the terms and conditions of the Creative Commons Attribution (CC-BY) license (https://creativecommons.org/licenses/by/4.0/). 
plant-dwelling phytophagous insects with several pest species that inspired numerous studies of their biology, ecology, feeding habits and conditions of their plant environment [3]. This knowledge represents the important and valuable background for investigating communication by chemical, mechanical and visual signals adapted for efficient transmission through air and substrate [4] and for developing various biorational control methods [5]. The present review starts with a description of the stink bug's general biology, ecology, feeding habits and environment. Environmental conditions and properties of transmission media have determined characteristics of chemical, mechanical and visual signals. The authors then present a comparative overview on characteristics of stink bug chemical and mechanical signals, together with the evolution of signal production and sensory mechanisms. The review terminates by describing the recognition, orientation, rivalry and social conflict processes that take place during group mating behavior.

The authors are aware that this review on stink bug communication is incomplete. We can expect that comparative studies among stink bugs and other groups will represent exceptions that will in the future enable a broader and deeper understanding of communication in plant-dwelling insects.

\section{2- Biology and Environment}

Stink bugs (Pentatomidae) represent the fourth largest family of Heteroptera with nine subfamilies, about 900 genera and more than 4,700 species [6]. This relatively small group of solitary living insects contains several invasive and economically important pest species $[3,7]$. Pentatomidae are predominantly plant feeders, with the exception of the subfamily Asopinae whose species feed principally on soft-bodied dipteran, lepidopteron and hymenopteran larvae [8]. The subfamily Pentatominae represents the most diverse pentatomide subfamily with over 2,800 species, divided into more than 40 tribes. Pentatominae feed and mate exclusively on different host plants, although generalists like Nezara viridula (L.) prefer brassicaceous plants and legumes [9]. Species that feed predominantly on immature seeds and fruits move in their absence to plants available at the time where they stay [10]. Many polyphagous stink bugs that feed preferentially on plants of particular taxa get attracted to them at long distance by their physical and/or chemical traits, such as chemical volatiles, surface waxes, nutrients and secondary compounds [10]. Preference for certain taxa is not genus-specific and, for example, Chinavia, Dichelops, Euschistus, Nezara, Palomena, Piezodorus and Thyanta species gather on soybean, wild beans and other legumes [3, 7, 9-12]. Less-preferred alternative host plants from families Amaranthaceae, Solenaceae and Fabaceae attract non-specific species like N. viridula, Piezodorus guildinii (Westwood), Euschistus heros (Fabr.), Edessa meditabunda (Fabr.), Dichelops furcatus (Fabr.), Dichelops melacanthus (Dallas) and Thyanta perditor (Fabr.) [10]. This less-preferred associated host may improve stink bug fitness when it complements the diet or in the lack of host plants [13].

The life cycle of Pentatomidae includes the reproductive and non-reproductive (hibernation, diapause) phases. Saulich and Musolin [14] investigated diapause in 43 stink bug species from the Temperate Zone, with the majority of them hibernating as adults, just two species overwintering as nymphs and another two as eggs. Day-length and temperature induce most Pentatominae to enter adult diapause irrespective of their feeding preferences. Obligate diapause was described in Palomena prasina (L.) and Palomena angulosa (Motschulsky). In Menida scotti (Puton) the obligate diapause for females was confirmed, with males remaining active over winter. During diapause $N$. viridula adults migrate to hidden places, change color and decrease the metabolic rate [15]. Santos and co-workers [16] demonstrated abdominal fat hypertrophy in the early stage of diapausing in Oebalus poecillus (Fabr.). During diapausing the authors measured decreased amount of body fat filled in the abdominal cavity. Dimensions of ovaries and testes steadily increase during development from immature to reproductive phase [16]. O. poecillus males reach sexual maturation inside and females outside the hibernation sites.

Profound knowledge on stink bug biology, ecology, life cycle and feeding habits gives a solid basis to understand the group's highly invasive status in different environments on all continents except the Arctic and Antarctic. Stink bug population success depends on efficient communication during reproductive behavior in the field by attraction of dispersed mates to meet on the same plant, where mating proceeds to copulation during calling, courtship and rivalry phases. During these processes stink bugs communicate on a long-range scale in the field by air-transmitted chemical signals, on a middle-range scale on a plant by substrate-borne vibratory signals and over a short distance by visual, airborne and contact mechanical and chemical signals.

\section{3- Reproductive Behavior and Communication}

Reproductive behavior of solitary stink bugs runs through different phases, starting in the field with long-range attraction of mates to meet on a plant, and there it proceeds to copulation by rivalry, calling and courtship. Communication provides information on species identity and directionality of movement to reach the calling mate, and it resolves social conflicts in imbalanced sex conditions.

Attraction and calling in the field to the same plant are mediated by male-produced sex pheromone attracting only females in Neotropical species and aggregates conspecific adult males, females and nymphs in Nearctic [17, 18]. Recently Borges and Blassioli-Moraes [17] and Weber et al. [18] reviewed data on chemical structure of the stink bug semiochemicals and their role during communication. 
Vibratory calling signals provide information on sender's species identity and mediate vibrational directionality of a searching mate's movement on a plant. Stink bug female and male calling song signals described so far show several common group characteristics [19]. In the majority of species the presence of a male triggers the female to start vibrational communication by emission of the calling song. The dominant frequency of the female calling song signals ranges between 70 and $180 \mathrm{~Hz}$ and different temporal characteristics of pulses or pulse trains provide information on species identity. Efficient information on calling female position on the plant is enabled by long-lasting emission of calling signals emitted with steady temporal characteristics from the same place. Males usually produce the calling song as a response to female emissions to keep her calling during searching behavior. In a few species males start vibrational communication spontaneously by emission of the male calling song, which triggers female response. The dominant frequency of signals varies between 74 and $145 \mathrm{~Hz}$, and different temporal parameters provide information on species identity [19].

Investigations of the early phase of mating behavior on a plant in N. viridula [20] confirmed that the male pheromone triggers female calling. Males, on the other hand, started vibrational communication when presented with a live female rotating its antennae and, furthermore, staying alone on a plant, males spontaneously emitted the calling song more often than females. Male calling motivates the female to produce the female calling song not as a response to the male but as the long-lasting leading emission, triggering different male reactions including moving and searching, responding with different vibratory signals and increasing the amount of emitted pheromone [21]. N. viridula males respond to female calling with short sequences of the calling song pulses that soon evolve to the courtship song pulse trains, and these represent the regular response to female calling at distances that excluded communication contact by signals of other modalities. Žunič et al. [22] demonstrated that males alone on the plant respond to played-back natural or synthesized female calling song signals more often with the courtship than calling song signals.

The courtship phase of stink bug of mating behavior, described first by Fish and Alcock [23] in Chlorochroa ligata (Say) and Cosmopepla bimaculata (Thomas) was confirmed in other pentatomine species like Nezara antennata (Scott) and N. viridula [24, 25, 26], Chinavia hilare (Say) [27]), Thyanta custator accera (Fabr.) and Thyanta pallidovirens (Stål) [28], Euschistus conspersus (Uhler) [29], E. meditabunda [30], D. melacanthus [31], Chinavia impicticornis (Stål) [32] and Chinavia ubica (Rolston) [33]. The authors described short range communication with substrate-transmitted courtship songs, antennation and butting in all species investigated so far. The courtship phase of mating behavior is shorter when compared with long-lasting calling phase and its underlying mechanisms are under-investigated. Courtship songs enable the final recognition of the mate and mutual motivation to proceed to copulation. Courtship song signals are more complex compared with those of the calling song and their species-specificity is based on various combinations of pulses and pulse trains, differing significantly in their duration and repetition time [19].

Emission of courtship songs follows calling, and their final song pattern develops through different transitional forms. The $N$. viridula male courtship song, for example, evolves from the male calling song pulses by their increased repetition rate, fusing them into distinct pulse trains. In a well-established duet, males emit courtship song pulses in intervals between female calling song signals to avoid their overlapping. [34].The male courtship song pulse trains develop from long male calling song pulses in E. heros, E. conspersus, C. ubica and T. perditor males. E. conspersus and $T$. perditor males emit two types of courtship songs. Similar evolution of male courtship song signals has been described in P. prasina, Palomena viridissima (Westwood) [35], T. custator accera and T. pallidovirens [28]. The opposite process has been described in C. hilaris [27], C. ligata, Chlorochroa sayi (Stål), C. uhleri (Stål) [36], C. impicticornis [32], Murgantia histrionica (Hahn) [37], D. melacanthus [31], E. meditabunda [30] and Holcostethus strictus (Fabr.) [38]. Female calling song triggers emission of the male calling song pulse trains, which evolve to the courtship song by disruption of pulse trains into sequences of readily repeated pulses.

The female courtship song, described in 15 stink bug species [19] is triggered by male courting and lasts a shorter time; its pattern of combined pulses and/or pulse trains shows less regularity compared with calling songs. The female courtship song pulse trains develop from the female calling song pulses in C. impicticornis [32], C. ubica [33] and N. viridula [34]. Complex courtship song pulse trains constituted by shorter and longer pulses are emitted by $C$. uhleri [36] and $P$. guildinii [32]. T. custator accera and T. pallidovirens [28] female courtship song is composed of several second long FM pulses. On the other hand, female courtship songs of D. melacanthus [31], E. conspersus [29], H. strictus [38] and $N$. antennata [39] are characterized by less than 0.5 second-long pulses. Male courting triggers female emission of the courtship song, accompanied by visual, chemical and mechanical communication contacts.

Female and male competition for access to copulation during the rivalry phase of mating behavior has been described in imbalanced sex conditions. Cross-attraction aggregates a different number of conspecific and heterospecific males and females on a plant [17], inducing social conflicts expressed by rivalry. Male rivalry is triggered by the female calling song and male pheromone induces female rivalry in the calling phase of mating behavior on a plant.

Male rivalry has been described in pentatomine species $C$. impicticornis, C. ligata and C. sayi, D. melacanthus, E. heros, $M$. histrionica, $N$. viridula, $P$. guildinii and $T$. perditor [19]. Rivalry between two males is expressed as alternation of readily repeated pulses of duration varying between species from $0.4 \mathrm{~s}$ in $N$. viridula [34] to above $1.3 \mathrm{~s}$ in $C$. 
impicticornis [32] and repetition time between minimal and maximal means of 0.6 in M. histrionica [37] and 1.6 seconds in P. guildinii [32]. Spectral characteristics of the male rival song signals differ from other vibrational emissions by pronounced FM varying around group-characteristic dominant frequency between minimal and maximal means at 96 $\mathrm{Hz}$ in D. melacanthus [31] and $149 \mathrm{~Hz}$ in E. heros [32]. Male rivalry was recorded either in the calling or courtship phase of mating behaviour, and is characterized by duetting with rival song pulses evolving from male calling or courtship song signals. The pattern of male rivalry differs in C. ligata [36] and in E. heros [32]. C. ligata [36] male rival duets are characterized by irregular exchange rival song signals and E. heros [32] males emit the rival song signals as a response to the other male calling song pulses. Females remain silent until the winning male proceeds to call and court again.

Female rivalry has been first described among Pentatomidae only recently in C. impicticornis, C. ubica, E. heros [40] and $N$. viridula [41]. It differs significantly from male rivalry by running at different levels with signals of different temporal and frequency characteristics, modified actively during rivalry. Female rivalry starts in all the four investigated species in the early phase of mating behavior between females, calling the same male on the plant. Competing females alternate at the lowest level with synchronized calling song signals. $C$. impicticornis females proceed to the higher rivalry level either by disruption of pulse trains to a sequence of single pulses or by their transition to the pulse trains of the second type. The competing female either stops calling at the first or second rivalry level, or changes the first type of the female calling song pulse trains to the second type over various transitional forms. The highest level of the species female rivalry is characterized by alternation of the second type of the female calling song pulse trains, which finally silences one of them. Rivalry in C. ubica females starts by duetting with the first or second type of the female calling song signals and proceeds to the higher level by synchronized alternation with the rival song pulse trains of complex structure, highly variable duration and extensive frequency modulation (FM). Less regular rival duetting with the female calling song signals evolves in E. heros females to alternation with the frequency modulated pulse trains of various temporal characteristics. Contrary to both Chinavia species, E. heros males during rivalry continue to emit their vibrational responses overlapping female signals.

The study on female rivalry in the pentatomine species $N$. viridula [41] addressed questions on species specificity of the process and on the plasticity of temporal and frequency parameters of female signals emitted during rivalry. The first rivalry level is characterized by female duets with the female calling song pulses, in which one of them changes the calling song pulses to the rival song pulse trains of three types. Rivalry proceeds at the lowest level by emission of the rival song pulse trains composed of pulses with similar duration and repetition time. At the higher level, one female increases the amplitude and duration of the first pulse of the pulse train above the others. Female rivalry terminates at the third level by emission of single pulses originating from the pronounced first pulse of the previous rivalry level pulse trains. The other female of a rival duet follows the leading one with delayed transitions from the calling to different types of the female rival song signals. Consequently, the authors recorded rival duets composed of different types of alternated signals, and the process terminates at any of their combinations. During rivalry, females vary alternated signals duration, repetition time and frequency characteristics to avoid interference of overlapped signals, to advertise their presence and to silence the competitor. Changing of the signal dominant frequency within the same sequences from 60 to $180 \mathrm{~Hz}$ by the same female suggests the more important role of signal frequency for its discrimination during vibrational communication on a plant.

\section{4- Communication through Air and Substrate}

Solitary-living stink bugs need to communicate in the field through media with different signal transmission properties. Air and substrate have different impacts on characteristics of transmitted signals and, consequently, insects need to use signals of various modalities and of characteristics, adapted to preserve information at the above signal-tonoise threshold at biologically relevant communication distances.

The first phase of stink bug communication takes place in the field by chemical signals transmitted between mates through the air. Air represents the medium through which small lipophilic molecules disperse by diffusion and advection [42] from higher to lower concentration. Wind, temperature and humidity direct their flow in pressure gradient conditions. The communication distance depends on wind velocity and varies when molecules are emitted and transmitted in the open air or within plant environment that absorbs and changes profiles of insect-released chemical signals. Theoretical calculations of the flow using complex mathematical models, supported by direct measurements in the field in different environmental conditions estimate communication distances up to 100 meters.

Plant-dwelling stink bugs communicate along the plant preferentially by the substrate-borne component of vibratory signals, produced by different mechanisms. Information on mate location on a plant by airborne chemical signals is less effective, being limited by local air currents and various plants' architecture. Vision and touch can be used only at short distance. Plants strongly attenuate airborne sound of higher frequencies and small body-sized insects cannot produce low frequency airborne sound of significant intensity [43]. Nevertheless, Eriksson et al. [44] described signalling between a male and female leafhopper Scaphoideus titanus (Ball) by vibratory signals transmitted over the air at a six 
cm distance between mechanically isolated leaves. Kavčič et al. [45] confirmed airborne communication up to six cm distance in the stink bug species E. heros. During transmission through the air between mechanically isolated leaves, signal spectra become narrower by increased attenuation of frequencies above $300 \mathrm{~Hz}$, and the signal's amplitude decreases by 20 to $30 \mathrm{~dB}$ at three $\mathrm{cm}$ and by 25 to $35 \mathrm{~dB}$ at six $\mathrm{cm}$ distance. Furthermore, we cannot exclude potential communication by air particle movements in the acoustic near-field.

Plants represent the non-inert type of medium for transmission of insect vibratory signals [46-48]. Michelsen et al. [47] proved that insects communicate through plants by the use of bending waves that propagate with a frequency that depends on velocity and with non-linear amplitude decay. The authors demonstrated low pass filter properties of plants transmitting vibrations of frequencies around $100 \mathrm{~Hz}$ with lowest attenuation. Spectral characteristics of stink bugs' vibratory signals are tuned with mechanical properties of their host plants and these enable efficient communication across meter-long distances [49]. Communication range depends on the plant's size, architecture and mechanical properties of its different parts. Amplitude, frequency and temporal characteristics of input vibratory signals change during transmission through the plant according to the distance between emitter and receiver.

Low-frequency stink bug signals, produced by vibration of abdomen (see below) with the main emitted energy below $200 \mathrm{~Hz}$, are adapted for efficient transmission through plants [49]. Stronger damping of vibrations above $400 \mathrm{~Hz}$ has been confirmed in burrowing bug species Scaptocoris carvalhoi (Becker) and Scaptocoris castanea (Party) (Cydnidae) [50]. Spectra of species stridulatory signals, recorded on soybean roots, extend up to $5 \mathrm{kHz}$. When recorded on the plant $28 \mathrm{~cm}$ above the soil, spectra narrow to the range below $300 \mathrm{~Hz}$ with characteristic frequency peaks around $100 \mathrm{~Hz}$. Spectra of plant-recorded asopine species Podisus maculiventris (Say) percussion signals showed extensive attenuation of higher frequency components when compared with signals recorded on the non-resonant substrate [51]. Frequencies of signals recorded simultaneously on the pronotum of singing $N$. viridula and on the plant directly below differ only by plant-induced subdominant components above 300 and below $80 \mathrm{~Hz}$ [49]. Polajnar and co-workers [52] described in $P$. prasina (L.) significant frequency differences of vibrational signal recorded on the non-resonant substrate, woody or herbaceous plant. The median dominant frequency of all signals ranged around $100 \mathrm{~Hz}$ for signals recorded on loudspeaker membrane, around $96 \mathrm{~Hz}$ for those recorded on hazel and bean and around $110 \mathrm{~Hz}$ for sedge recorded ones.

Frequency-dependent propagation velocity of bending waves changes the pattern of FM signals at different distances from the source. Propagation velocity increases with increasing frequency and consequently the delay between low and high-frequency components of FM signals increases with the distance. The resolution of FM delay pattern in signals recorded, for example in Chlorochroa species [36] or Piezodorus lituratus (Fabr.) [53] may provide information on the distance to the source. The spectral peak amplitudes of stink bug vibratory signals vary with the distance between the emitter and receiver by minima and maxima repeated regularly around $20 \mathrm{~cm}$ for the dominant peak of about $100 \mathrm{~Hz}$ and around $10 \mathrm{~cm}$ for its first harmonic (see below). Frequency-dependent propagation velocity and regular amplitude variation with the distance change the ratio of spectral peak amplitudes. At certain distances between the emitter and receiver one can record signals of the amplitude of the first harmonic, exceeding the one of the dominant frequency [54].

The velocity of vibratory signals, measured on the pronotum of $N$. viridula and of $M$. histrionica, varied individually between 0.3 and $0.8 \mathrm{~mm} / \mathrm{s}$ for bugs singing on the plant (Cyperus alternifolius leaf) and around $0.9 \mathrm{~mm} / \mathrm{s}$ for those singing on the non-resonant substrate (loudspeaker) [54]. Velocity of signals measured on the plant immediately below the singing $N$. viridula varied between $5.6 \mathrm{~dB}$ above and $1.6 \mathrm{~dB}$ below the input value determined on the pronotum. At the distance of less than $1 \mathrm{~cm}$ from the singing $M$. histrionica bug, the velocity of signals recorded on the loudspeaker membrane ranged around $0.2 \mathrm{~mm} / \mathrm{s}$ and varied around values of $0.5 \mathrm{~mm} / \mathrm{s}$ for bladderpot leaf, $1.3 \mathrm{~mm} / \mathrm{s}$ for ivy and 2.3 $\mathrm{mm} / \mathrm{s}$ for London rocket leaf recorded signals [54].

Vibratory signals are transmitted through the plant with low internal damping [47]. Individual frequency attenuation of band-limited noise, transmitted through banana leaves, varied between 0.3 and $0.4 \mathrm{~dB} / \mathrm{cm}$ [2]. The amplitude of vibrations transmitted through rod-like parts of a plant (stem, big leaf veins) decreases non-linearly [47], and its regular variation with the distance from the source was demonstrated in N. viridula for playback [55] and naturally emitted [54] vibratory signals. The velocity of calling song signals, emitted by two females on the sedge leaf, decreased by 1.5-2.5 $\mathrm{dB} / \mathrm{cm}$ when transmitted through the cyperus leaves, by $15-19 \mathrm{~dB} / \mathrm{cm}$ when transmitted from leaves to the stem and by $0.06 \mathrm{~dB} / \mathrm{cm}$ (re. $0.07 \mathrm{~mm} / \mathrm{s}$ ) or for $0.1 \mathrm{~dB} / \mathrm{cm}$ (re. $0.11 \mathrm{~mm} / \mathrm{s}$ ) when transmitted through the stem [54]. Michelsen and co-workers [47] suggested that low and high signal amplitudes at nodes and antinodes occur on the stem in standing wave conditions by signals travelling several times up and down the plant with low attenuation. Polajnar and co-workers [56], on the other hand, confirmed the hypothesis that regularly repeated velocity peaks are caused by plant resonance.

Transmission of vibratory signals through leaf veins differs from transmission through lamina by lower damping of higher frequency components and by non-linear velocity variation with the distance [37, 57].

Duration of vibratory signals transmitted through plants with low attenuation increases by resonance and echoes, occurring by reflection at the phase between substrate and air [47]. Signal duration increases proportionally with the distance from the source and may become an obstacle for its recognition. Miklas et al. [58] demonstrated that $N$. viridula 
males differentiated pulses from pulse trains of the conspecific female calling song when playback experiments were conducted on the non-resonant substrate but not on the plant. Duration of fast repeated pulse train pulses increased during transmission through the plant, and males recognized pulse trains with fused pulses as single pulses.

Communication through a narrow frequency window decreases the impact of noise outside the band limited range. On the other hand, the efficiency of signal recognition by its spectral characteristics decreases. Polajnar and Čokl [59] (2008) demonstrated that $100 \mathrm{~Hz}$ disturbance vibration has no effect on the $N$. viridula male when searching the calling female, but inhibits male emission of vibratory response signals. Females exposed to $100 \mathrm{~Hz}$ noise either stopped calling or changed the repetition rate and dominant frequency of the calling song signals to increase the difference with the 100 $\mathrm{Hz}$ pure tone disturbance vibration. Pure tone vibrations of 75 to $200 \mathrm{~Hz}$ increased the proportion of the Neotropical brown stink bug E. heros females to sing spontaneously and inhibited male signaling and searching. The 75 to $100 \mathrm{~Hz}$ noise almost completely reduced copulation. In long-term experiments, background noise delayed and slightly reduced mating frequency by $24.7 \%$ [60].

Wind, falling water drops and anthropogenic noise are the main abiotic factors that potentially disturb substrateborne vibratory communication of plant-dwelling insects. The dominant frequency of wind-vibrated banana leaves lies below $10 \mathrm{~Hz}$ [61], and Casas et al. [62] measured the basic frequency of fluttering leaves between $7 \mathrm{man} 10 \mathrm{~Hz}$ for parallel and between 7 and $14 \mathrm{~Hz}$ for perpendicular flow, independently of wind speed. The up to $60 \mathrm{~mm} / \mathrm{s}$ velocity of leaf vibrations, induced by low-speed wind, may increase to above $100 \mathrm{~mm} / \mathrm{s}$ at high speed. Spectra of vibrations, produced by water drops or insects landing on a leaf, are characterized by the high frequency and irregular amplitude phase, followed by a low-frequency regular phase, whose amplitude exponentially decreases by a half-life of around 0.163 [62]. The spectral characteristics of stink bug abdomen vibration produced signal ranges outside the low and high-frequency components of the noise produced by wind and falling water drops.

\section{5- Production and Characteristics of Communication Signals}

Chemical signals, produced by dimorphic cells, cuticular, metathoracic and abdominal glands, play the important role in mediating stink bug reproductive behavior [17]. Sex and aggregation pheromones have been experimentally confirmed as the key communication signals in N. viridula by Borges et al. [26]. The authors demonstrated the longrange attraction of conspecific females to male-released pheromone, identified in species' abdominal sternites [63] as trans-(Z)-bisabolene epoxide and the corresponding cis isomer [17]. The latter components of the same stereochemistry were identified also in pheromone blends of Chinavia spp. [64]. Communication distance in the field has not been precisely measured, but field experiments with pheromone-baited traps estimated a distance of approximately $100 \mathrm{~m}$ [65].

Up-to-date results on semiochemistry in Pentatomidae and different aspects of stink bug communication with chemical signals have been recently reviewed by Borges and Blassioli-Moraes [17] (2017). Sex, aggregation and alarm pheromones, allomones, kairomones and synomones are involved in intra- and interspecific chemical contacts between stink bugs, their natural enemies and host plants. The authors summarized data on the role of pheromones in different phases of communication during reproductive and mating behavior in the majority of species. Advanced studies including detailed bioassays, chemical structure, field trials and commercial development have been conducted in few species like [65] E. heros and Halyomorpha halys (Stål) [17]. Pheromones produced exclusively by males have a sexual function in most species, with the exception of Piezodorus hybneri Gmelin, in which they act as sexual or aggregation signals [66].

Species and sex-specific cuticular hydrocarbons have been described in stink bugs Bagrada hilaris Burmeister [67], N. viridula [68], C. ubica and C. impicticornis [69]. Cuticular hydrocarbons present in footprints are used by egg parasitoids as kairomones [70-72] and it is only indirectly suggested that they play a role in stink bug reproductive behavior. B. hilaris males, for example, tried to copulate with significantly fewer female bodies with extracted cuticular hydrocarbons [73]. Footprints absorbed in the plant's epicuticle may act as long-lasting signals [74], and their role in reproductive behavior has been suggested by Zgonik and Čokl [20], who hypothesized that spontaneous emission of the female calling song, is caused by sensing footprints left on a plant previously occupied by males.

Stink bugs produce communication signals of components transmitted through air and substrate by vibration of abdomen, body tremulation, vibration of lifted wings (buzzing) and percussion. Contact mechanical signals are produced prior to copulation by antennation and butting of mate's body.

The main repertoire of species and sex-specific calling, courtship and rival signals is produced by vertical vibration of abdomen without touching the substrate. The fused first and second abdominal tergites form the plate, anteriorly connected by a pair of strong longitudinal muscles to thoracic metaphragma and posteriorly with another set of muscles to the anterior ridge of the third abdominal tergit [75]. The plate is laterally connected with the abdominal wall by lateral compressor muscles and the depressor tymbali muscle. Kuštor [76] recorded during emission of vibratory signal electromiograms (EMG) from muscles connecting the plate with the thorax and abdomen. The author confirmed 
synchronous activity of plate tergal and lateral compressor muscles, recorded in the phase with cycles of produced vibratory signals. Amon [77] electrically stimulated the brain of N. viridula to induce singing and simultaneously recorded substrate vibrations, electromiograms (EMG) of the plate muscles and activity of corresponding motor neurons. The author demonstrated that each cycle of the emitted vibratory signal is preceded by the motor neuron action potential that triggers EMG potential of the corresponding muscle, driving the cyclic up-and-down movement of the abdomen. The frequency of the produced vibratory signal is determined by the repetition rate of one-to-one correlated neuronal and muscular potentials with cycles of the vibrational signal.

Vibratory songs, defined as a continuous sequence of signals with a clear start and end, are named according to their behavioral context as calling, courtship, rival and copulatory. Song parameters are described by the frequency and temporal characteristics of their constituting signals, determined as pulses or pulse trains. Pulses are defined as unitary homogeneous parcels of vibrations of finite duration, and pulse trains as temporally distinct groups of pulses. Frequency characteristics are described by the dominant frequency, spectral width and FM. Signal temporal characteristics are expressed by pulse or pulse train duration and repetition time. The amplitude parameter is usually represented in velocity $(\mathrm{m} / \mathrm{s}$ or $\mathrm{mm} / \mathrm{s})$ units.

The list of until now identified and described stink bug vibrational signals [4] includes Aelia acuminata (L.), Carpocoris fuscispinus (Boheman), Carpocoris purpuriepennis (De Geer), Carpocoris pudicus (Poda) [78], C. impicticornis [32], C. ubica [33], C. hilare [27], Chlorochroa juniperina (L.), Chlorochroa pinicola (Mulsan \& Rey) [78], C. ligata, C. uhleri, C. sayi [36], Codophila varia (Fabr.) [78], D. melacanthus [31], Dolycoris baccarum (L.) [78], E. meditabunda [30], Eurydema ornata (L.), E. oleracea (L.) [78], E. conspersus [29], E. heros [32], Graphosoma semipunctatum (Fabr.), Graphosoma lineatum (L.) [78], Halyomorpha halys (Stål) [79], H. strictus [38], Holcostethus vernalis (Wolff) [78], M. histrionica [37], N. antennata [39], N. viridula [34], P. prasina, P. viridissima [35], Pentatoma rufipes (L.) [78], P. guildinii [32], P. lituratus [53], Staria lunata (Hahn) [78], T. custator accera, T. pallidovirens [28] and T. perditor [32].

Vibrational signals produced by the same emission mechanism have been investigated also in Asopinae predatory stink bugs Arma custos (Fabr.), Troilus luridus (Fabr.) and Zicrona caerulea (L.) [80], Podisus maculiventris (Recimo) [51], Podisus nigrispinus (Dallas) [81] and Picromerus bidens (L.) [80, 82].

Data on frequency and temporal characteristics of until now identified and described stink bugs' signals produced by abdomen vibration have been recently summarized [19]. The main emitted energy is produced in the frequency range below $200 \mathrm{~Hz}$, with the dominant frequency centered around $100 \mathrm{~Hz}$ and the lowest mean value at $62 \mathrm{~Hz}$ in C. ligata [36], while the highest is at $175 \mathrm{~Hz}$ in E. heros [32]. Spectra are characterized by a different number of harmonic peaks in the frequency range below $600 \mathrm{~Hz}$.

Spectra of abdomen vibration signals in Asopinae species A. custos, T. luridus, Z. caerulea [80], P. bidens [80, 82], P. maculiventris [51] and P. nigrispinus [81] differ by their broad-band characteristics and different dominant frequency values measured for the same song type [83]. The first dominant frequency of the male song of $P$. maculiventris varies between 90 and $140 \mathrm{~Hz}$ [51] and in P. bidens between 75 and $250 \mathrm{~Hz}$ [82].

Stink bug songs differ significantly by various temporal characteristics of combined pulses and pulse trains. Duration and repetition time parameters of the calling, courtship and rival song pulses and/or pulse trains have been recently reviewed in Pentatominae [19] and Asopinae [74], with a newly described song repertoire in the pentatomine species $H$. halys [79]. Temporal characteristics of copulatory songs, recorded in several stink bug species immediately after copulation, differ by minute-long sequences of 0.04 to $0.1 \mathrm{~s}$ short pulses, repeated readily every 0.1 to $0.8 \mathrm{~s}$ [19].

Overlapping of stink bug vibrational signals of similar frequency causes interference, thus significantly changing their parameters. Stink bugs tend to modify signal duration and repetition time during calling, courtship and rivalry duetting to establish alternation without overlapping. Overlapping of $N$. viridula female calling song signals by long male courtship song responses has been recorded before their synchronization, and in E. heros the consequence was recently [84] described of interference in the temporal, frequency and amplitude modulation pattern of masked signals together with mates' strategies to preserve information within the complex vibration. The readily repeated female calling song pulses trigger and overlap the male calling signal when the response latency of the latter is shorter than female signal duration, or when the duration of the male signal exceeds the interval between consecutive female ones without inhibition of the latter. The amplitude and temporal pattern of overlapped signals change to a sequence of readily repeated and fused pulses. Their duration and amplitude decrease with increased difference between frequencies of overlapped vibrations. Females and males tend to avoid interference or to minimize its effects by emission of signals with changed temporal characteristics and, when overlapped, by changing their frequency and FM characteristics to increase the difference between values of masked signals.

During mating behavior stink bugs also produce less species-specific vibratory signals by tremulation of the whole body, vibration of lifted wings (buzzing) and by percussion. Tremulatory signals are produced by vigorous shaking of the whole body parallel to the substrate, with legs firmly standing on it $[51,81,82]$. Tremulatory signals produced in 
Pentatominae [45] and Asopinae [81] share common amplitude, temporal and frequency characteristics. The characteristic plant-recorded tremulatory signals of amplitudes up to $5 \mathrm{~mm} / \mathrm{s}$, duration below $0.5 \mathrm{~s}$ and irregular repetition rate are composed of a short, high frequency onset followed by the longer low frequency tail with the decaying amplitude resembling plant resonance.

Buzzing signals, produced by vibration of lifted wings, represent another less species-specific high-amplitude vibratory emission [45]. The velocity of E. heros plant-recorded buzzing signals reached $40 \mathrm{~mm} / \mathrm{s}$, and the duration of irregularly produced signals varied within and between individuals from $0.5 \mathrm{~s}$ to minute-long continuous emissions. Buzzing signals differ from other vibrational signals by their spectra, characterized by the narrow dominant frequency peak around $100 \mathrm{~Hz}$ and its harmonics reaching $1500 \mathrm{~Hz}$.

Percussion signals are produced by drumming with front legs on the plant [51,85], or by striking with abdomen against the substrate [78]. Percussion (drumming) signals of P. maculiventris [51] and E. heros [45] are characterized by pulse duration between 0.1 and $0.13 \mathrm{~s}$, regular repetition time between 0.46 to $0.51 \mathrm{~s}$, the dominant frequency below $200 \mathrm{~Hz}$ and by velocities below $0.5 \mathrm{~mm} / \mathrm{s}$.

Contact mechanical signals produced by mutual antennation and butting of the mate's body have been observed prior to copulation without data on their physical characteristics $[28,32,86]$. Signalling by touch is under-investigated mainly because of technically demanding experiments including description of signal parameters, their relevant reproduction and recording of receptor and higher order neurons by simultaneous vibration of the body by high amplitude signals.

Vision enables the selection of insect host plant, among other activities [87]. Zgonik and Čokl [20] suggested that visual signals may play a potential role in stink bug close-range courtship. Presentation of a live $N$. viridula female, rotating antennae when getting close to the male, induced in daylight (not in the dark) increased male emission of vibratory signals. Capone [88] described female and male preference for copulation with a larger mate in stink bug Acrosternum (Chinavia) hilare. We can hypothesize that mates may estimate body size by different antenna length, as shown in Acheta domesticus (L) (Orthoptera: Gryllidae) by Khadka et al. [89]. Functional characteristics of stink bug visual receptor cells detecting the above-mentioned behavioral patterns have not been investigated yet.

\section{6- Interaction of Signals of Different Modalities}

Unimodal signals carry a unique component, being detected by a single specialized receptor after transmission through a single channel. Multimodal signals are transmitted via different channels, carrying several components that are detected by different receptors and multicomponent ones with different components exciting different receptors after transmission through a single channel [90]. Although communication with multimodal signals attracts a higher number of predators, insects often use them to decrease the impact of environmental noise [91] and to increase the efficiency of the sensory and neuronal system [92] by extracting the information sequentially, transmitted by different rate and at different distances [93]. Sex pheromones [17, 18] belong to the group of unimodal signals, together with visual [20], contact chemical and mechanical ones used at short distance before copulation [26, 30, 33, 86, 94]. Mechanical signals produced by vibration of the body or its different parts represent the multimodal signals because their airborne and substrate-borne components are transmitted through different media and are detected by different receptors. Communication with the airborne component of vibrations produced by plant-dwelling insects has been confirmed in leafhoppers [44], predatory stink bugs [51] and Pentatominae [45]. Further studies need to explain its role during communication also by less investigated high amplitude signals produced by vibration of lifted wings and tremulation of the whole body.

The interaction and synergy of contact signals produced immediately before and after copulation by antennation, butting, tapping [28, 32, 33, 86] and scraping of the female abdomen with the hind legs [19] is poorly understood. The role of the stink bug cuticular carbons during courtship communication also needs further studies.

Mutual interaction of chemical and vibratory signals has been described in N. viridula [21]. The authors recorded increased emission of pheromones by $N$. viridula males stimulated by playback of the conspecific female calling song. Species and sex-specificity of this interaction has been confirmed by playback of the conspecific male rival song or 100 $\mathrm{Hz}$ signals that had no effect on male pheromone emission. The authors measured the highest emission after the end of stimulation and suggested that vibratory stimulation increases the rate of pheromone biosynthesis and excretion. The $N$. viridula male pheromone also triggers conspecific female emission of the calling song and visual signals produced by females, and rotating their antennae increases the intensity of male calling song emission, according to Zgonik and Čokl [20].

\section{7- Sensory and Neuronal System}

Successful reproductive behavior depends on efficient detection and processing of information, encoded in various parameters of chemical, mechanical or visual signals. Internal and external noise demands evolution of sensory and neuronal mechanisms that extract the information by increasing signal-to-noise ratio at different levels. During evolution, stink bugs adapted various receptors to detect signals of different modalities and characteristics with high 
sensitivity and selectivity, tuned with properties of different transmission media. Most studies have been focused until now on the anatomy and function of stink bug chemo- and mechanoreceptors. Less attention has been paid to the receptors involved in the stink bug close-range courtship phase of communication on a plant.

Up-to-date knowledge on semiochemistry and chemoreceptors in Pentatomidae has been recently reviewed by Borges and Blassioli-Moraes [17] and Weber et al. [18]. Morphology of olphactory sensilla, situated mainly on antennae, has been described in N. viridula [95], Cyclopelta siccifolia Westwood and Chrysocoris purpurea Westwood [96], P. guildinii, D. melacanthus and E. heros [97]. The lower number of basiconic sensilla on antennae in male stink bug species E. heros, E. meditabunda and P. guildinii compared with conspecific females suggests their detection of odors [97]. Experimental studies are needed to confirm interaction between odorant binding proteins identified in $E$. heros, $C$. ubica and D. melacanthus [98].

Mechanoreceptors sensitive to substrate vibrations are situated on and within the stink bug body. The anatomy of the mechanoreceptor cells that are most sensitive to substrate vibration has been described in the legs of $N$. viridula by Michel et al. [99]. Each leg is equipped with a complex of different sensory organs including the subgenual organ, joint chordotonal organs and non-grouped campaniform sensilla. The subgenual organ, composed of two scolopidia, each with one sensory cell, is situated within the blood channel in the upper part of the tibia. The body of the organ is proximally fixed at the blood channel wall and, distally, by the flag-like ligament at its different parts close to the tibio-tarsal joint. The femoral chordotonal organ is the most complex one, composed of eight scolopidia in the condensed and four scolopidia in the dispersed scoloparium. The tibial distal chordotonal organ with two scolopidia and the tarso-praetarsal chordotonal organ with two scoloparia control joints are found between tibia and tarsus and between tarsus and praetarsus respectively.

Threshold curves of the $N$. viridula leg vibratory receptor organ complex revealed a group of receptor cells tuned to low frequencies and two cells responding best to higher frequencies [100]. The low-frequency vibratory receptor neurons are tuned to frequencies below $100 \mathrm{~Hz}$ with best velocity sensitivity between 0.1 and $0.01 \mathrm{~mm} / \mathrm{s}$ between 50 and $70 \mathrm{~Hz}$. Their threshold curves follow the line of equal displacement values and their phase-coupled responses efficiently code signal frequency and FM pattern in the range below $100 \mathrm{~Hz}$. Two receptor cells are tuned to detect vibrations of higher frequencies. One of them responds with around $0.01 \mathrm{~mm} / \mathrm{s}$ highest threshold sensitivity to vibrations of frequencies around $190 \mathrm{~Hz}$, and the other one shows best sensitivity between 500 and $1000 \mathrm{~Hz}$ with threshold around $0.001 \mathrm{~mm} / \mathrm{s}$. Threshold curves of both higher frequency receptor neurons follow the line of equal acceleration values below and the line of equal displacement values above the best frequency.

The low-frequency receptor neurons originate in joint chordotonal organs and campaniform sensilla, and responses of both higher frequency receptor neurons are attributed to both subgenual organ sensory cells. Zorović [101] described in $N$. viridula central projections and terminal arborisations of leg vibratory receptor neurons within separate neuropiles, situated at the ipsilateral site of the prothoracic ganglion and in meso- and metathoracic neuromers of the central ganglion. Each vibratory neuropile is composed of two parts. Both higher-frequency receptor cells finally terminate in the neuropile's central part, and receptor cells of the low-frequency group arborise with the anteriorly oriented arches and side branches, diverging at the entrance of the leg nerve into the corresponding segment of the ventral cord.

Recently, Nishino et al. [102] enlarged the number of stink bug mechanoreceptors that might at least indirectly contribute to different processes of vibratory communication. In the stink bug Plautia stali (Scott) the authors described morphology and central projections of the abdominal pleural and ventral group of chordotonal organs, together with the tymbal chordotonal organ situated in the abdomen. The latter organ is attached with four sensory cells to the ligament connecting the cuticular ridge of metathorax and the abdominal sternites. The ligament is fixed to the tymbal muscles over the surface of the fatty body. The authors have shown that leg, antennal and abdominal chordotonal organ receptor cells finally terminate in the same ventral cord neuropiles.

Jeram and Pabst [103] described in N. viridula the anatomy of the antennal chordotonal organ complex. The Johnston's and the central chordotonal organs show relevant sensitivity to vibrations of antennae in the frequency range up to $140 \mathrm{~Hz}$ with the threshold around two mm/s between 30 and $60 \mathrm{~Hz}$ [104]. Such antennal frequency and amplitude sensitivity allows detection of substrate vibrations induced by high-amplitude tremulatory and buzzing signals, and suggests their role during antennation of the mate's body during courtship.

High-amplitude tremulatory signals are regularly produced over a short distance between stink bug mates before copulation. We hypothesize that induced air particle movement can be detected in the acoustic near-field by hair sensilla. High sensitivity of trichobotria has been shown for example in the firebug Pyrrhocoris apterus (Fallen) (Heteroptera: Pyrrhocoridae) [105]. The author recorded their responses to airborne oscillations produced by a flying fly at the distance of $30 \mathrm{~cm}$. For more information on the anatomy and function of trichobotria see Barth [2]. Schaefer [106] described trichobotria on the abdomen in Thaumastellidae, Urostylidae, Corimelaenidae, Cydnidae, and Pentatomidae. Trichobotria of Pentatominae stink bugs are situated close to the spiracular line on the third and forth abdominal segment [107]. Although the role of trichobotria in stink bug close-range courtship has not been experimentally confirmed, we 
hypothesize that they may detect the high-amplitude and low-frequency airborne component of tremulatory and buzzing signals.

Functional properties of stink bug neurons processing vibratory signal characteristics have been until now investigated in $N$. viridula at the peripheral level $[103,108]$. The authors described in the thoracic ventral cord ten types of interneurons. Five different types of ascending neurons receive their synaptic input in the metathoracic and one with two (bilaterally) ascending axons in the mesothoracic neuromere of the central ganglion. Three different types of local interneurons are restricted to the same neuromere of the central ganglion. The soma of the one identified descending vibratory interneuron is situated in the prothoracic ganglion and its descending axon projects to the central ganglion at the contralateral site. The $N$. viridula vibratory interneurons are compared with less sensitive receptor neurons and their response pattern is more complex. Interneurons of one group are tuned to frequencies below $100 \mathrm{~Hz}$, and those of the other to a broader frequency range, characteristic of the receptor neuron, responding best around 200 Hz. Zorović [109] confirmed that filtering of temporal characteristics of $N$. viridula vibratory communication signals occurs at the periphery of the species' central nervous system at the level of four different types of the ascending ventral cord neurons.

\section{8- Recognition and Directionality of Chemical and Mechanical Signals}

Stink bugs in the field need to recognize, find and compete for the mate. Species recognition has been described as the process of responding preferentially or ultimately to conspecific mate species-specific signal characteristics. Directionality of movement during searching for a mate in the field runs parallel with recognition processes and leads to courtship and copulation, including potential social conflicts in sex-imbalanced conditions. The main processes of stink bug reproductive behavior are mediated by communication with uni- and multimodal signals.

Recognition of the mate underlies processes that take place throughout all the different phases of mating behavior. Over a long distance in the field, the more or less species-specific pheromone emitted by male attracts dispersed solitary stink bugs to gather on the same plant [26]. Although different ratios of the major components provide stink bugs with pheromone species-specificity, Borges and Blassioli-Moraes [17] summarized data on several examples of sex and aggregation pheromone cross-attraction. $N$. antennata, for example, reacts to the $N$. viridula sex pheromone with a different ratio of components. Furthermore, $N$. viridula is attracted to the T. perditor sex pheromone that blends completely different characteristics, and the sex pheromone of $P$. stali attracts $H$. halys and $C$. hilaris [110,111]. Crossattraction has been demonstrated also by a mixture of $P$. stali and $E$. servus pheromones attracting the latter individuals [112], as well as by the Thyanta perditor synthetic sex pheromone, which showed cross-attraction to E. heros, E. meditabunda, $P$. guildinii and $N$. viridula [113].

Studies of stink bug species recognition on the plant have been conducted by analyzing the stereotyped behavioral pattern expressed in the majority of species by male reactions to the female vibratory calling song signals. The level of female calling song recognition has been determined by the correlation of quality and quantity of male responses (emission of vibratory signals and directional movement) with different parameters of female natural emissions or of artificially synthesized calling song signals reproduced on non-resonant substrate or on the plant. Žunič et al. have shown [22] that males recognize the conspecific female calling song signals by their duration and repetition time in the broad frequency range from 70 to $180 \mathrm{~Hz}$. Although males reacted best to playback signals of temporal and frequency parameters that are characteristic of naturally emitted song, the authors recorded their responses in their broader range. Recognition takes place at a lower level by playback signals of several times longer duration and repetition rate. On the other hand, responding decreases sharply for playback pulses shorter than $0.7 \mathrm{~s}$ and repeated at intervals below one second.

C. impicticornis and C. ubica share a similar pattern of reproductive behavior and vibratory song repertoire. Laumann et al. [33] demonstrated that insects responding to heterospecific signals terminate mating behavior at its early stage, suggesting that species isolation occurs in both Chinavia species during the calling phase. Recognition is based on different temporal patterns of female signals [114].

The broad response range can be explained by differences in signal characteristics expressed within the same or between different populations. $N$. viridula female calling song signal duration differed significantly between individuals of the same population collected at the same place in seasons 1999 [34] and 2011 [22]. N. viridula dispersed from Africa to all continents (except Arctic and Antarctic), where members of geographically isolated populations with genetically confirmed differences [115] emit signals with temporal parameters characteristic of specific population during common pattern of reproductive behavior [34]. These differences did not prevent calling behavior and communication between populations from Brazil and Slovenia [116]. Miklas et al. [117] demonstrated that males of the populations from France and Guadeloupe at one site preferred to respond to conspecific female emissions but, at the other, males also searched for females of the alien population emitting the calling song of different temporal parameters. Signal temporal parameter differences between the Australian and Slovene N. viridula populations [118] prevented females from Australia from recognizing and responding to the Slovene male calling song, although Slovene females readily responded and copulated with males from Australia [119]. Recognition of statistically evaluated differences in stink bug female calling song 
signal characteristics does not always provide privacy of communication through a plant. Hrabar et al. [120] demonstrated that $N$. viridula males did not differentiate the conspecific female calling song from $T$. custator accera male second song pulses, which carry similar temporal and frequency characteristics. Interspecific copulation has been described in natural conditions in the field between sympatrically distributed $N$. antennata and $N$. viridula populations in Japan [121], although their vibratory song repertoire differs significantly [39].

Abiotic noise has limited impact on stink bug recognition processes because communication runs through a narrow frequency window with decreased sensitivity to low-frequency vibrations produced for example by moderate wind and water drops sporadically falling on the plant. Biotic noise, produced by several stink bug emissions within the group's characteristic spectral range, overlaps calling and courtship duets and decreases the recognition of species-specific signals. De Groot et al. [122] demonstrated that simultaneously reproduced conspecific or heterospecific vibratory signals decrease $N$. viridula male responsiveness to female calling, with a lower effect on searching behavior than on responding by calling or courtship song signals. In the following investigation, the authors [123] demonstrated that $N$. viridula male responsiveness decreases when conspecific female calling song signals arrived from two sources, because of significantly changed duration of overlapped signals or as a consequence of increased high repetition rate recognized within the same sequence as a song produced by a single female. Searching behavior of $N$. viridula males was not significantly changed by simultaneous stimulation with a conspecific and heterospecific (C. hilaris) female calling song. Males preferred to orient themselves towards the source of $C$. hilaris signals when overlapped with conspecific ones.

Overlapping of vibratory communication signals causes interference that significantly changes their amplitude modulation pattern and frequency characteristics [84]. Stink bug reactions seek to avoid the effects of overlapping by modulations of signal frequency and time characteristics to increase signal-to-noise ratio, as mentioned above.

Directional movement of stink bugs is mediated in the field by chemical signals and on the plant by vibratory signals transmitted through the substrate. Highly volatile and relatively stable molecules of sex pheromones are transported through air in pressure gradient conditions and enable stink bugs' recognition and directional flying over a long distance in the field $[17,18]$. The efficiency of both processes depends on environmental impacts like direction and velocity of wind, temperature, humidity or mechanical barriers; furthermore, they are degraded by UV radiation and subjected to isomerization by reacting with oxygen. The efficiency of stink bug attraction by pheromones has been recently described in reviews by Laumann et al. [124] and Tillman et al. [125]. Local air currents, humidity and temperature gradients, together with leaf barriers, decrease the efficiency of mate localization on a plant by sex pheromones. The use of cuticular hydrocarbons left in footprints to direct stink bug walking on a plant needs to be experimentally confirmed.

Vibrational directionality has been described in arthropods on different substrates, as for example in the nocturnal scorpion Paruroctonus mesaensis (Stahnke) [126], the wandering spider C. salei [127] and the southern green stink bug N. viridula $[128,129]$. ) Common to all of them is recognition of directionality by detection and processing of the amplitude difference and of the time delay between vibratory inputs arriving from different directions on spatially separated sensory organs. Stritih et al. [130] demonstrated that $N$. viridula stink bugs detect a difference in the amplitude of vibratory signals on the crossing between the plant's stem and petiolus. Recent investigation on directional cues mediating vibrational directionality in $N$. viridula [131] confirmed that frequency-dependent amplitude variation with the distance from the source [54] creates various amplitude differences at the two branches of a crossing; at certain distances, amplitude values on the side away from the source may exceed those on the side leading to the calling mate. With the low-frequency-dependent propagation velocity of bending waves [47] we can expect the time delay from 0.25 to $0.5 \mathrm{~ms}$ for about $100 \mathrm{~Hz}$ vibratory signals measured on two branches of a crossing at the distance of two $\mathrm{cm}$. This value lies above the $0.2 \mathrm{~ms}$ threshold determined for vibrational directionality investigated in scorpions by Brownell and Farley [126]. As expected, Prešern et al. [131] recorded above-threshold 0.4 ms mean time difference for signals recorded on the ipsi- and contralateral side of the crossing at distances around $2 \mathrm{~cm}$. The authors concluded that only this information is the reliable directional cue underlying vibrational directionality on a plant. Neuronal processing of directionality based on 1-3 ms of time difference in leg stimulation was first described in insects in Locusta migratoria [131]. Prešern et al. [131] recorded in N. viridula neuronal discrimination of directional cues at around $0.5 \mathrm{~ms}$ of time differences between them, by certain $N$. viridula ventral cord vibratory interneurons, described previously by Zorović et al. [108].

\section{9- Conclusion}

Stink bugs are a highly successful group of insects with several economically important and invasive pest species. The globally important pest status of the group has inspired intensive investigations of different stink bug species' biology and ecology. The population's success is also a result of the evolution of efficient multimodal communication in different environments and under various conditions. Plant-dwelling solitary stink bugs exchange information by chemical, mechanical and visual signals transmitted through air and substrate. Signal characteristics are tuned with properties of different media to preserve information in parameter(s) that are less influenced by transmission and by environmental noise. The group's sensory system is adapted to show its highest sensitivity in the narrow band-pass 
range of signal characteristics that carry the relevant information. Airborne chemical signals enable mates to meet on the plant and, once there, the substrate-borne component of vibratory signals guides them to meet over a short distance. The terminal phase of courtship includes communication with visual, contact chemical and mechanical signals. Mating behavior includes the calling and courtship phases. Social conflict leads to rivalry between females and between males in imbalanced sex conditions. The results of basic studies of different complex communication processes have inspired the development of various biological control techniques.

\section{0- Funding}

The review was financially supported by the Slovenian Research Agency (research core funding No. P1-0255 B, project No. J1-8142) and the Research Support Foundation of the Federal District (FAP-DF) (project No. 193.000.978/2015).

\section{1- Acknowledgments}

The authors are grateful to all colleagues who contributed their references in the present review article. The authors dedicate this work to their teachers, colleagues, students and friends who understood their curiosity and helped them. We thank Mrs. Susan Casement for improving the language of the text.

\section{2- Conflict of Interest}

The author declares that there is no conflict of interests regarding the publication of this manuscript. In addition, the ethical issues, including plagiarism, informed consent, misconduct, data fabrication and/or falsification, double publication and/or submission, and redundancies have been completely observed by the authors.

\section{3- References}

[1] Bradbury, Jack W., and Sandra.L. Vehrencamp. "Principles of Animal Communication" (August 2011). Sunderland: Sinauer Associates Incorporated.

[2] Barth, Friedrich G. “A spider’s world: senses and behavior” (2002). Berlin: Springer. doi:10.1007/978-3-662-04899-3.

[3] Panizzi, Antonio .R., John E. McPherson, David .G. James, M. Javahery, and Robert M. McPherson. "Stink bugs (Pentatomidae)." In C. W. Schaefer and A.R. Panizzi (eds.), "Heteroptera of Economic Importance," (July 2000): 421-474. Boca Raton: CRC Press. doi: 10.1201/9781420041859.

[4] Čokl, Andrej, Maria C. Blassioli-Moraes, Raul A. Laumann, Alenka Žunič, and Miguel Borges. "Stinkbugs - multisensory communication with chemical and vibratory signals transmitted through different media." In P.S.M. Hill, R. Lakes-Harlan, V. Mazzoni, P.M. Narins, M. Virant-Doberlet, and A. Wessel (eds.), "Biotremology - Studying Vibrational Behavior," (2019). Berlin: Springer (in press).

[5] Čokl, Andrej, and Miguel Borges. "Stink Bugs: Biorational Control Based on Communication Processes" (March 2017). Boca Raton London New York: CRC Press Taylor \& Francis Group. doi:10.1201/9781315120713.

[6] Grazifl, Jocelia, and Cristiano Schweriner. "Chapter 1. Stink Bug Classification, Phylogeny, Biology and Reproductive Behavior." Stink Bugs (April 30, 2017): 1-30. doi:10.1201/9781315120713-2.

[7] McPherson, John E., and Robert M. McPherson. "General Introduction to Stink Bugs.” Stink Bugs of Economic Importance in America North of Mexico (September 19, 2000). doi:10.1201/9781420042429.ch1.

[8] Clercq, Patrick De. "Predatory Stink Bugs (Hemiptera: Pentatomidae, Asopinae)." Encyclopedia of Entomology 3 (August 2008): 1826-1828. doi:10.1007/0-306-48380-7_3399.

[9] Todd, James W., and Donald C. Herzog. "Sampling Phytophagous Pentatomidae on Soybean." Sampling Methods in Soybean Entomology (1980): 438-478. doi:10.1007/978-1-4612-9998-1_23.

[10] Panizzi, Antonio, and Tiago Lucini. “Chapter 2 Host Plant-Stink Bug (Pentatomidae) Relationships.” Stink Bugs (April 30, 2017): 31-58. doi:10.1201/9781315120713-3.

[11] Smaniotto, Lisonéia F., and Antônio R. Panizzi. "Interactions of Selected Species of Stink Bugs (Hemiptera: Heteroptera: Pentatomidae) from Leguminous Crops with Plants in the Neotropics.” Florida Entomologist 98, no. 1 (March 2015): 7-17. doi:10.1653/024.098.0103.

[12] Grazia, Jocélia, Antônio R. Panizzi, Caroline Greve, Cristiano F. Schwertner, Luiz A. Campos, Thereza de A. Garbelotto, and José Antônio Marin Fernandes. "Stink Bugs (Pentatomidae).” Entomology in Focus (2015): 681-756. doi:10.1007/978-94-0179861-7_22.

[13] Da Silva, Cleonor Cavalcante Alves, Maria Carolina Blassioli-Moraes, Miguel Borges, and Raúl Alberto Laumann. "Food 
Diversification with Associated Plants Increases the Performance of the Neotropical Stink Bug, Chinavia Impicticornis (Hemiptera: Pentatomidae)." Arthropod-Plant Interactions 13, no. 3 (September 1, 2018): 423-429. doi:10.1007/s11829-0189637-6.

[14] Saulich, A. Kh., and D. L. Musolin. "Diapause in the Seasonal Cycle of Stink Bugs (Heteroptera, Pentatomidae) from the Temperate Zone.” Entomological Review 92, no. 1 (March 2012): 1-26. doi:10.1134/s0013873812010010.

[15] Harris, V. E., J. W. Todd, and B. G. Mullinix. "Color change as an indicator of adult diapause in the southern green stink bug, Nezara viridula." Journal of Agricultural Entomology 1 (1984): 82-91.

[16] Santos, R. S. S., L. R. Redaelli, L. M. G. Diefenbach, H. P. Romanowski, and H. F. Prando. "Characterization of the Imaginal Reproductive Diapause of Oebalus Poecilus (Dallas) (Hemiptera: Pentatomidae).” Brazilian Journal of Biology 63, no. 4 (November 2003): 695-703. doi:10.1590/s1519-69842003000400017.

[17] Borges, Miguel, and Maria Carolina Blassioli-Moraes. "Chapter 5. The Semiochemistry of Pentatomidae.” Stink Bugs (April 30, 2017): 95-124. doi:10.1201/9781315120713-6.

[18] Weber, Donald C., Ashot Khrimian, Maria Carolina Blassioli-Moraes, and Jocelyn G. Millar. "Semiochemistry of Pentatomoidea." Invasive Stink Bugs and Related Species (Pentatomoidea) (January 17, 2018): 677-726. doi:10.1201/9781315371221-15.

[19] Čokl, Andrej, Raul Alberto Laumam, and Natasa Stritih. "Chapter 6 Substrate-Borne Vibratory Communication." Stink Bugs (April 30, 2017): 125-164. doi:10.1201/9781315120713-7.

[20] Zgonik, Vera, and Andrej Čokl. "The Role of Signals of Different Modalities in Initiating Vibratory Communication in Nezara Viridula.” Open Life Sciences 9, no. 2 (January 1, 2014): 200-211. doi:10.2478/s11535-013-0253-2.

[21] Miklas, Nadège, Thérèse Lasnier, and Michel Renou. "Male bugs modulate pheromone emission in response to vibratory signals from conspecifics." Journal of chemical ecology 29, no. 3 (March 2003): 561-574. doi:10.1023/a:1022898620429.

[22] Žunič, Alenka, Meta Virant-Doberlet, and Andrej Čokl. "Species Recognition during Substrate-Borne Communication in Nezara Viridula (L.) (Pentatomidae: Heteroptera).” Journal of Insect Behavior 24, no. 6 (June 11, 2011): 468-487. doi:10.1007/s10905011-9272-x.

[23] Fish J., and J. Alcock. "The behavior of Chlorochroa ligata (Say) and Cosmopepla bimaculata (Thomas) (Hemiptera: Pentatomidae)." Entomology News 84, (October 1973): 260-268.

[24] Mitchell, Wallace C., and Ronald F. L. Mau. "Sexual Activity and Longevity of the Southern Green Stink Bug, Nezara Viridula1,2." Annals of the Entomological Society of America 62, no. 6 (November 17, 1969): 1246-1247. doi:10.1093/aesa/62.6.1246.

[25] Harris, Vivienne E., and James W. Todd. "Temporal and Numerical Patterns of Reproductive Behavior in the Southern Green Stink Bug, Nezara Viridula (Hemiptera: Pentatomidae).” Entomologia Experimentalis et Applicata 27, no. 2 (March 1980): 105116. doi:10.1111/j.1570-7458.1980.tb02954.x.

[26] Borges, M., P. C. Jepson, and P. E. Howse. "Long-Range Mate Location and Close-Range Courtship Behaviour of the Green Stink Bug, Nezara Viridula and Its Mediation by Sex Pheromones.” Entomologia Experimentalis et Applicata 44, no. 3 (August 1987): 205-212. doi:10.1111/j.1570-7458.1987.tb00546.x.

[27] Čokl A., H.L. McBrien, and J.G. Millar. "Comparison of substrate-borne vibrational signals of two stink bug species, Acrosternum hilare and Nezara viridula (Heteroptera: Pentatomidae).” Annual Review of Entomological Society of America 94, (May 2001): 471-479. doi:10.1603/0013-8746(2001)094[0471:COSBVS]2.0.CO;2.

[28] McBrien H.L., A. Čokl, and J.G. Millar. "Comparison of substrate-borne vibrational signals of two consperse stink bug species, Thyanta pallidovirens and T. custator accera (Heteroptera: Pentatomidae).” Journal of Insect Behavior 15, no. 6 (November 2002): 715-738. doi:10.1023/A:1021164021489

[29] McBrien, Heather L., and Jocelyn G. Millar. "Substrate-Borne Vibrational Signals of the Consperse Stink Bug (Hemiptera: Pentatomidae)." The Canadian Entomologist 135, no. 4 (August 2003): 555-567. doi:10.4039/n02-078.

[30] Silva, Cleonor Cavalcante A., Raul Alberto Laumann, Jonatas Barbosa Cavalcante Ferreira, Maria Carolina Blassioli Moraes, Miguel Borges, and Andrej Čokl. "Reproductive Biology, Mating Behavior, and Vibratory Communication of the BrownWinged Stink Bug,Edessa meditabunda(Fabr.) (Heteroptera: Pentatomidae).” Psyche: A Journal of Entomology 2012 (2012): 1-9. doi:10.1155/2012/598086.

[31] Blassioli-Moraes, Maria C., Diego M. Magalhães, Andrej Čokl, Raúl A. Laumann, Joseane P. Da Silva, Cleonor C. A. Silva, and Miguel Borges. "Vibrational Communication and Mating Behaviour ofDichelops melacanthus(Hemiptera: Pentatomidae) Recorded from Loudspeaker Membranes and Plants." Physiological Entomology 39, no. 1 (November 14, 2013 ): 1-11. doi:10.1111/phen.12041. 
[32] Moraes, Maria Carolina Blassioli, Raul Alberto Laumann, Andrej Cokl, and Miguel Borges. "Vibratory Signals of Four Neotropical Stink Bug Species." Physiological Entomology 30, no. 2 (June 2005): 175-188. doi:10.1111/j.13653032.2005.00446.x.

[33] Laumann, Raul A., Andrej Čokl, Maria Carolina Blassioli-Moraes, and Miguel Borges. "Vibratory Communication and Its Relevance to Reproductive Isolation in Two Sympatric Stink Bug Species (Hemiptera: Pentatomidae: Pentatominae)." Journal of Insect Behavior 29, no. 6 (October 29, 2016): 643-665. doi:10.1007/s10905-016-9585-x.

[34] Čokl, Andrej, Meta Virant-Doberlet, and Natasa Stritih. "The Structure and Function of Songs Emitted by Southern Green Stink Bugs from Brazil, Florida, Italy and Slovenia.” Physiological Entomology 25, no. 2 (June 2000): 196-205. doi:10.1046/j.13653032.2000.00187.x.

[35] Čokl, Andrej, M. Gogala and A. Blaževič "Principles of Sound Recognition in Three Pentatomide Bug Species (Heteroptera)." Biološki Vestnik (Ljubljana) 26, (1978): 81-94.

[36] Bagwell G.J., A. Čokl, and J.G. Millar. "Characterization and comparison of the substrate-borne vibrational signals of Chlorochroa uhleri, C. ligata and C. sayi." Annual Review of Entomological Society of America 101, no. 1 (January 2008): 235246. doi:10.1603/0013-8746(2008)101[235:CACOSV]2.0.CO;2.

[37] Čokl, Andrej, Janez Presern, Meta Virant-Doberlet, Glen J. Bagwell, and Jocelyn G. Millar. "Vibratory Signals of the Harlequin Bug and Their Transmission through Plants." Physiological Entomology 29, no. 4 (September 2004): 372-380. doi:10.1111/j.0307-6962.2004.00395.x.

[38] Pavlovčič, P., and A. Čokl. "Songs of Holcostethus Strictus (Fabricius): a Different Repertoire among Landbugs (Heteroptera: Pentatomidae)." Behavioural Processes 53, no. 1-2 (March 2001): 65-73. doi:10.1016/s0376-6357(00)00144-3.

[39] Kon, Masahiro, Akemi Oe, Hideharu Numata, and Toshitaka Hidaka. "Comparison of the Mating Behaviour Between Two Sympatric species,Nezara Antennata andN. Viridula (Heteroptera: Pentatomidae), with Special Reference to Sound Emission." Journal of Ethology 6, no. 2 (December 1988): 91-98. doi:10.1007/bf02350873.

[40] Čokl, Andrej, Aline Moreira Dias, Maria Carolina Blassioli Moraes, Miguel Borges, and Raul Alberto Laumann. "Rivalry Between Stink Bug Females in a Vibrational Communication Network.” Journal of Insect Behavior 30, no. 6 (November 2017): 741-758. doi:10.1007/s10905-017-9651-z.

[41] Čokl, Andrej, Alenka Žunič Kosi, Raul Alberto Laumann, and Meta Virant - Doberlet. "Female Competition for Availability of Males in Insects: The Nezara Viridula (Linnaeus, 1758) Model.” Insect Science (June 12, 2019). doi:10.1111/1744-7917.12692.

[42] Weissburg, MJ. “The Fluid Dynamical Context of Chemosensory Behavior.” The Biological Bulletin 198, no. 2 (April 2000): 188-202. doi:10.2307/1542523.

[43] Markl, Hubert. "Vibrational Communication.” Neuroethology and Behavioral Physiology (1983): 332-353. doi:10.1007/978-3642-69271-0_24.

[44] Eriksson, Anna, Gianfranco Anfora, Andrea Lucchi, Meta Virant-Doberlet, and Valerio Mazzoni. "Inter-Plant Vibrational Communication in a Leafhopper Insect." Edited by Wulfila Gronenberg. PLoS ONE 6, no. 5 (May 5, 2011): 1-6. doi:10.1371/journal.pone.0019692.

[45] Kavčič, Andreja, Andrej Čokl, Raúl A. Laumann, Maria Carolina Blassioli-Moraes, and Miguel Borges. "Tremulatory and Abdomen Vibration Signals Enable Communication through Air in the Stink Bug Euschistus Heros." Edited by Keith A. Crandall. PLoS ONE 8, no. 2 (February 27, 2013): 1-10. doi:10.1371/journal.pone.0056503.

[46] Cremer Lothar, and Manfred Heckl, and E.E. Ungar. "Structure-borne sound, structural vibrations and sound radiation at audio frequencies" (1973). Berlin Heidelberg New York: Springer. doi:10.1007/978-3-662-10118-6.

[47] Michelsen, Axel, Flemming Fink, Matija Gogala, and Dieter Traue. "Plants as Transmission Channels for Insect Vibrational Songs.” Behavioral Ecology and Sociobiology 11, no. 4 (December 1982): 269-281. doi:10.1007/bf00299304.

[48] Michelsen, Axel. "Physical aspects of vibrational communication." In R.B. Cocroft, M. Gogala, P.S.M. Hill and A. Wessel (eds), "Studying Vibrational Communication," (July 2014): 199-213. Heidelberg New York Dordrecht London: Springer. doi:10.1007/978-3-662-43607-3_11.

[49] Čokl, A., M. Zorović, A. Žunič and M. Virant-Doberlet, "Tuning of host plants with vibratory songs of Nezara viridula L. (Heteroptera: Pentatomidae).” Journal of Experimental Biology 207, (February 2005): 1481-1488. doi:10.1242/jeb.01557.

[50] Čokl, A., C. Nardi, J.M.S. Bento, E. Hirose, and A.R. Panizzi. "Transmission of stridulatory signals of the burrower bugs, Scaptocoris castanea and Scaptocoris carvalhoi (Heteroptera: Cydnidae) through the soil and soybean." Physiological Entomology 31, (October 2006): 371-381. doi:10.1111/j.1365-3032.2006.00530.x.

[51] Žunič, A., M. Virant-Doberlet, and A. Čokl. "Communication with signals produced by abdominal vibration, tremulation and percussion in Podisus maculiventris (Heteroptera: Pentatomidae).” Annual Review of Entomological Society of America 101, no. 6 (November 2008): 1169-1178. doi:10.1603/0013-8746-101.6.1169. 
[52] Polajnar, J., A. Kavčič, A. Žunič, and A. Čokl. "Palomena prasina (Hemiptera: Pentatomidae) vibratory signals and their tuning with plant substrates." Central European Journal of Biology 8, no. 7 (March 2013): 670-680. doi:10.2478/s11535-013-0188-z.

[53] Gogala, M., and R. Razpotnik. "Method of oscillographic sonagraphy for bioacoustic research.” Biološki Vestnik (Ljubljana) 22, (1974): 209-216.

[54] Čokl, A., M. Zorović, and J.G. Millar. "Vibration communication along plants by the stink bugs Nezara viridula and Murgantia histrionica.” Behavioural Processes 75, (May 2007): 40-54. doi:10.1016/j.beproc.2007.01.003.

[55] Čokl, A. "Vibratory signal transmission properties in plants measured by laser vibrometry." Periodicum biologorum 90, (1988): 193-196.

[56] Polajnar J, D. Svenšek, and A. Čokl. "Resonance in herbaceous plant stems as a factor in vibrational communication of pentatomide bugs (Heteroptera: Pentatomidae)." Journal of Royal Society Interface 9, (February 2012): 898-1907. doi: 10.1098/rsif.2011.0770.

[57] Magal, C., M. Schöller, J. Tautz, and J. Casas. "The role of leaf structure in vibration propagation.” Journal of Acoustic Society of America 198, (November 2000): 2412-2418. doi:10.1121/1.1286098.

[58] Miklas, N., N. Stritih, A. Čokl, and M. Virant-Doberlet. "The influence of substrate on male responsiveness to the female calling song in Nezara viridula." Journal of Insect Behavior 14, no. 3 (May 2001): 313-332. doi:10.1023/A:1011115111592.

[59] Polajnar, J., and A. Čokl. "The effect of vibratory disturbance on sexual behaviour of the southern green stink bug Nezara viridula (Heteroptera, Pentatomidae).” Central European Journal of Biology 3, no. 2 (January 2008): 189-197. doi:10.2478/s11535-0080008-7.

[60] Laumann R.A., D.H.B. Maccagnan, A. Čokl, M.C. Blassioli-Moraes, and M. Borges. "Substrate-borne vibrations disrupt the mating behaviors of the Neotropical stink bug, Euschistus heros: implications for pest management." Journal of Pest Science 91, (February 2018): 995-1004. doi:10.1007/s10340-018-0961-5.

[61] Barth, F.G., H. Bleckmann, J. Bohnenberger, and E.A. Seyfarth.” Spiders of genus Cupiennius SIMON 1891 (Aranea, Ctenidae). II. On the vibratory environment of a wandering spider.” Oecologia 77, (November 1988): 191-201. doi: 10.1007/BF00379186.

[62] Casas, J., J. Bacher, J. Tautz, R. Meyhöfer, and D. Pierre. "Leaf vibrations and air movement in a leaf miner-parasitoid system." Biological Control 11(2), (February 1998): 147-153. doi:10.1006/bcon.1997.0593.

[63] Borges, M. "Attractant compounds of the southern green stink bug, Nezara viridula (L.) (Heteroptera: Pentatomidae)." Annals of the Entomological Society of Brazil 24, (1995): 215-225.

[64] Blassioli-Moraes, M.C., R.A. Laumann, M.W.M Oliveira, C.M. Woodcock, P. Mayon, A. Hooper, J.A. Pickett, M.A. Birkett, and M. Borges. "Sex pheromone communication in two sympatric Neotropical stink bug species Chinavia ubica and Chinavia impicticornis.” Journal of Chemical Ecology 38, (July 2012): 836-845. doi:10.1007/s10886-012-0142-6.

[65] Borges, M., M.C. Blassioli-Moraes, M.E. Peixoto, C.S.S. Pires, E.R. Suji, and R.A. Laumann. "Monitoring the Neotropical brown stink bug Euschistus heros (F.) (Hemiptera: Pentatomidae) with pheromone-baited traps in soybean fields." Journal of Applied Entomology 135, (February 2011): 68-80. doi:10.1111/j.1439-0418.2010.01507.x.

[66] Leal, W.S., S. Kuwahara, X. Shi, H., H. Higuchi, C.E. Marino, M. Ono, et al. "Male-released sex pheromone of the stink bug Piezodorus hybneri." Journal of Chemical Ecology 24, (November 1998): 1817-1829. doi:10.1023/A:1022307600446.

[67] De Pasquale, C., S. Guarino, E. Peri, G. Alonzo, and S. Colazza.'Investigation of cuticular hydrocarbons from Bagrada hilaris genders by SPME/GC-MS." Analytical and Bioanalytical Chemistry 389, (November 2007): 1259-1265. doi: 10.1007/s00216007-1503-9.

[68] Colazza, S., G. Aquila, C. De Pasquale, E. Peri, and J.G. Millar. "The egg parasitoids Trissolcus basalis uses n-nonadecane, a cuticular hydrocarbon from its stink bug host Nezara viridula, to discriminate between female and male hosts." Journal of Chemical Ecology 33, (July 2007): 1405-1420. doi:10.1007/s10886-007-9300-7.

[69] Silveira, Samantha da. "Isolamento Reprodutivo Em Duas Espécies Simpátricas de Chinavia Orian (Hemiptera: Pentatomidae): Importância Da Comunicação Vibracional e Composição Química Da Cutícula”, M.Sc. Thesis (2015), Universidade de Brasília, Brasilia, Brazil. doi:10.26512/2015.06.d.19228.

[70] Colazza, S., G. Salerno, and E. Wajnberg. "Volatile and contact chemicals released by Nezara viridula (Heteroptera: Pentatomidae) have a kairomonal effect on the egg parasitoids Trissolcus basalis (Hymenoptera: Scelionidae).” Biological Control 16, no. 3 (November 1999): 310-317. doi:10.1006.bcon.1999.0763.

[71] Borges, M., P.G.H. Zarbin, J.T.B., Ferreira, and M.L.M. da Costa. "Pheromone sharing: blends based on the same compounds for Euschistus heros and Piezodorus guildinii." Journal of Chemical Ecology 25, (March 1999): 629-634. doi:10.1023/A:1020914222769. 
[72] Lagôa, Ana Carolina Gomes. "Respostas Comportamentais Dos Parasitoides de Ovos Telenomus Podisi e Trissolcus Basalis (Hymenoptera: Platygastridae) a Rastros Químicos de Percevejos (Hemiptera: Pentatomidae)” MSc Thesis (2016), Universidade de Brasília, Brasilia, Brazil. doi:10.26512/2016.03.d.20346.

[73] Guarino, S., C. De Pasquale, E. Peri, G. Alonzo, and S. Colazza. "Role of volatile and contact pheromones in the mating behavior of Bagrada hilaris (Heteroptera: Pentatomidae)." European Journal of Entomology 105, (October 2008): 613-617. doi:10.14411/eje.2008.082.

[74] Colazza, S., M. Lo Bue, D. Giudice, and E. Peri. "The response of Trissolcus basalis to footprint contact kairomons from Nezara viridula females is mediated by leaf epicuticular waxes.” Naturwissenschaften 96, (May 2009): 975-981. doi: 10.1007/s00114009-0548-3.

[75] Malouf, N.S.R. "The skeletal motor mechanism of the thorax of the "stink bug" Nezara viridula L." Bulletin of the Royal Entomological Society of Egypt 16, (1932): 161-203.

[76] Kuštor, V. "Activity of muscles of the vibration producing organ of the bug Nezara viridula." Unpublished MSc thesis. University of Ljubljana, Ljubljana, Slovenia (1989).

[77] Amon, T. "Electrical brain stimulation elicits singing in the bugNezara viridula." Naturwissenschaften 77, no. 6 (1990): 291 292.

[78] Shestakov, L.S. "A comparative analysis of vibrational signals in 16 sympatric species (Pentatomidae, Heteroptera)." Entomological Review 95, no. 3 (June 2015): 310-325. doi:10.1134/S0013873815030045.

[79] Polajnar, J., L. Maistrello, A. Bertarella, and V. Mazzoni. "Vibrational communication of the brown marmorated stink bug (Halyomorpha halys)," Physiological Entomology 41, no. 3 (June 2016): 249-259. doi:10.1111/phen.12150.

[80] Shestakov, L. S. "Studies of Vibratory Signals in Pentatomid Bugs (Heteroptera, Asopinae) from European Russia." Entomological Review 88, no. 1 (March 2008): 20-25. doi:10.1134/s001387380801003x.

[81] Laumann R.A., A. Kavčič, M.C. Blassioli-Moraes, M. Borges, and A. Čokl. "Reproductive behaviour and vibratory communication of the Neotropical predatory stink bug Podisus nigrispinus." Physiological Entomology 38, (February 2013): 71-80. doi:10.1111/phen.12005.

[82] Čokl A., A. Žunič, and M. Virant-Doberlet. "Predatory bug Picromerus bidens communicates at different frequency levels." Central European Journal of Biology 6, (June 2011): 431-439. doi:10.2478/s11535-011-0015-y.

[83] Žunič Kosi, Alenka, and Andrej Čokl. "Chapter 3 Predatory Stink Bugs (Asopinae) and the Role of Substrate-Borne VibrationalSignals in Intra- and Interspecific Interactions.” Stink Bugs (April 30, 2017): 59-77. doi:10.1201/97813151207134.

[84] Čokl, A., R.A. Laumann, A. Žunič-Kosi, M.C. Blassioli-Moraes, M. Virant-Doberlet, and M. Borges. "Interference of overlapping insect vibratory communication signals: an Euschistus heros model.” PLoS One 10, no. 6 (June 2015): 1-16. doi:10.1371/journal.pone.0130775.

[85] Gogala, Matija. "Vibratory signals produced by Heteroptera-Pentatomorpha and Cimicomorpha." In, S. Drosopoulos and M.F. Claridge (eds.), "Insects Sound and Communication: Physiology, Behaviour, Ecology and Evolution," (November 2006): 275295. Boca Raton: CRC Press Taylor \& Francis Group. doi: 10.1201/9781420039337.pt2.

[86] Blassioli-Moraes, Maria Carolina, Miguel Borges, and Raul Alberto Laumann. "The Application of Chemical Cues in Arthropod Pest Management for Arable Crops.” Chemical Ecology of Insect Parasitoids (April 5, 2013): $225-244$. doi:10.1002/9781118409589.ch10.

[87] Pekar S., and M. Hruškova. "Coreus marginatus (Heteroptera: Coreidae) as a natural enemy of Rumex obtusifolius (Polygonaceae).” Acta Oecologia 28, no. 3 (November-December 2005): 281-287. doi:10.1016/j.actao.2005.05.004.

[88] Capone, T.A. "Mutual preference for large mates in green stink bugs, Acrosternum hilare (Hemiptera: Pentatomidae)." Animal Behavior 49, no.5 (May 1995): 1335-1344. doi:10.1006/anbe.1995.0165.

[89] Khadka, K.K., J. Shek, J. Hoffman, R. Vuhin, and M. Foellmer. “Longer antennae for Romeo: Assessing effect of antennae length on courtship and mating success in male crickets, Acheta domesticus (Orthoptera, Gryllidae)." Journal of Insect Behavior 25, (January 2012): 96-103. doi:10.1007/s10905-011-9281-9.

[90] Partan, S.R., and P. Marler. "Issues in the classification of multisensory communication signals." American Naturalist 166, (August 2005): 231-245. doi:10.1086/431246.

[91] Wilson, A.J., M. Dean, and J.P. Higham. “A game theoretic approach to multimodal communication.” Behavioral Ecology and Sociobiology 67, (September 2013): 1399-1415. doi:10.1007/s00265-013-1589-3.

[92] Rowe, C. "Receiver psychology and the evolution of multicomponent signals." Animal Behavior 58, (November 1999): 921931. doi:10.1006/anbe.1999.1242. 
[93] Uy, J.A.C., and R.J. Safran. "Variation in the temporal and spatial use of signals and its implications for multimodal communication.” Behavioral Ecology and Sociobiology 67, (September 2013): 1499-1511. doi:10.1007/s00265-013-1492-y.

[94] Zahn, Deane K., Jardel A. Moreira, and Jocelyn G. Millar. "Identification, Synthesis, and Bioassay of a Male-Specific Aggregation Pheromone from the Harlequin Bug, Murgantia Histrionica.” Journal of Chemical Ecology 34, no. 2 (January 19, 2008): 238-251. doi:10.1007/s10886-007-9415-x.

[95] Brézot, P., D. Tauban, and M. Renou. "Sense organs on the antennal flagellum of the green stink bug, Nezara viridula (L.) (Heteroptera: Pentatomidae): sensilla types and numerical growth during the post-embryonic development." International Journal of Insect Morphology and Embryology 25, (October 1996): 427-441. doi:10.1006/SOO20-7322(96)00012-8.

[96] Rani, U.P., and S.S. Madhavendra. "External morphology of antennal and rostral sensilla in four hemipteran insects and their possible role in host plant selection." International Journal of Tropical Insect Science 25, (September 2005): $198-207$. doi:10.1079/IJT200577.

[97] Silva, Cleonor C.A., Guy de Capdeville, Maria Carolina B. Moraes, Rosana Falcão, Lívia Fernandes Solino, Raul A. Laumann, Joseane P. Silva, and Miguel Borges. "Morphology, Distribution and Abundance of Antennal Sensilla in Three Stink Bug Species (Hemiptera: Pentatomidae).” Micron 41, no. 4 (June 2010): 289-300. doi:10.1016/j.micron.2009.11.009.

[98] Farias, Luciana R., Pedro H. C. Schimmelpfeng, Roberto C. Togawa, Marcos M. C. Costa, Priscila Grynberg, Natália F. Martins, Miguel Borges, et al. "Transcriptome-Based Identification of Highly Similar Odorant-Binding Proteins Among Neotropical Stink Bugs and Their Egg Parasitoid.” Edited by J Joe Hull. PLoS One 10, no. 7 (July 10, 2015). doi:10.1371/journal.pone.0132286.

[99] Michel, K., T. Amon, and A. Cokl. "The morphology of the leg scolopidial organs in Nezara viridula (L.)(Heteroptera, Pentatomidae)." Revue canadienne de biologie expérimentale 42, no. 2 (1983): 139-150.

[100] Čokl, A. "Functional properties of vibroreceptors in the legs of Nezara viridula (L.) (Heteroptera, Pentatomidae)." Journal of Comparative Physiology A 150, (June 1983): 261-269. doi:10.1007/BF00606376.

[101] Zorović, M. "Morphological and physiological properties of vibrational neurons in thoracic ganglia of the stink bug Nezara viridula (L.) (Heteroptera: Pentatomidae).” PhD Thesis (2005), University of Ljubljana.

[102] Nishino, H., H. Mukai, and T. Takanashi. "Chordotonal organs in hemipteran insects: unique peripheral structures but conserved central organization revealed by comparative neuroanatomy." Cell Tissue Research, (December 2016). doi:10.1007/s00441016-2480-0.

[103] Jeram, S., and A.M. Pabst. "Johnston's organ and central organ in Nezara viridula (L.) (Heteroptera, Pentatomidae)." Tissue and Cell 28, (April 1996): 227-235. doi:10.1016/S0040-8166(96)80011-5.

[104] Jeram, S. "Structure and function of Johnston's organ in the bug species Nezara viridula (L.).” Dissertation Thesis (1966), University of Ljubljana, Slovenia.

[105] Šolinc, G. "Influence of temporal and spatial properties of airflow on the response of filiform sensilla of the bug Pyrrhocoris apterus." MSc Thesis (2017), University of Ljubljana, Slovenia.

[106] Schaefer, C. "Heteropteran Trichobotria (Hemiptera: Heteroptera)." International Journal of Insect Morphology and Embryology 4, no. 3 (July 1975): 193-238. doi:10.1016/0020-7322(75)90034-3.

[107] Rolston, L.H., and F.J.D. McDonald. "Keys and diagnoses for the families of Western Hemisphere Pentatomoidea, subfamilies of Pentatomidae and tribes of Pentatominae (Hemiptera).” Journal of New York Entomological Society 87, (September 1979): 189-207.

[108] Zorović, M., J. Prešern and A. Čokl, "Morphology and physiology of vibratory interneurons in the thoracic ganglia of the southern green stinkbug Nezara viridula (L.)." Journal of Comparative Neurology 508, (May 2008): 365-381. doi:10.1002/cne.21656.

[109] Zorović, M. "Temporal processing of vibratory communication signals at the level of ascending interneurons in Nezara viridula (Hemiptera: Pentatomidae).” PLoS One 6, (October 2011): 1-8. doi:10.1371/journal.pone.0026843.

[110] Aldrich, J.R., A. Khrimian, and M.J., Camp. "Methyl 2,4,6-decatrienoates attract stink bugs and tachinid parasitoids.” Journal of Chemical Ecology 33, (April 2007): 801-815. doi:10.1007/s10886-007-9270-9.

[111] Aldrich, J.R., A. Khrimian, M.J. Camp, and X. Chen. "Semiochemically based monitoring of the invasion of the brown marmorated stink bug and unexpected attraction of the native green stink bugs (Heteroptera: Pentatomidae) in Maryland." Florida Entomologist 92, (September 2009): 483-491. doi:10.1653/024.092.0310.

[112] Tillman, P.G., J.R. Aldrich, A. Khrimian, and T. Cottrell. "Pheromone attraction and cross-attraction of Nezara, Acrosternum and Euschistus spp. stink bugs (Heteroptera: Pentatomidae) in the field.” Environmental Entomology 39, (April 2010): 610617. doi:10.1603/EN09114. 
[113] Laumann, R.A., M.C. Blassioli-Moraes, A. Khrimian, and M. Borges. "Field capture of Thyanta perditor with pheromone bated traps.” Pesq. Agropec. Bras., Brasília 46, no. 2 (February 2011): 113-119. doi:10.1590/S0100-204X2011000200001.

[114] Silveira, S. da, A.M. Dias, A.C. Gomes Lagoa, M.C. Blassioli-Moraes, M. Borges, A. Čokl, M., and R.A. Laumann. "Specificity of male responses to female vibratory signals in two Chinavia species (Hemiptera: Pentatomidae) is based on signal structure and narrow temporal parameters." Animal Behavior and Cognition 6, (February 2019): 1-12. doi:10.26451/abc.06.01.01.2019.

[115] Kavar, T., P. Pavlovčič, S. Sušnik, V. Meglič, and M. Virant-Doberlet. “ Genetic differentiation of geographically separated populations of the southern green stink bug Nezara viridula (Hemiptera: Heteroptera)." Bulletin of Entomological Research 96, (April 2006): 117-128. doi:10.1079/BER2005406.

[116] Virant-Doberlet, M., A. Čokl, and N. Stritih. "Vibratory songs of hybrids from Brazilian and Slovenian populations of the southern green stink bug Nezara viridula." Pflügers Archiv - European Journal of Physiology (July 2000) 439 (Supplement): R196-R198. doi:10.1007/s004240000143.

[117] Miklas, N., A. Čokl, M. Renou, and M. Virant-Doberlet. "Variability of vibratory signals and mate choice selectivity in the southern green stink bug." Behavioral Processes 61, (March 2003): 131-142. doi:10.1016/S0376-6357(02)00186-9.

[118] Ryan, M., A. Čokl, and G.H. Walter. "Differences in vibratory sound communication between the Slovenian and Australian population of Nezara viridula.” Behavioral Processes, 36, (April 1996): 183-193. doi:10.1016/0376-6357(95)00026-7.

[119] Jeraj, M., and G.H. Walter. "Vibrational communication in Nezara viridula: response of Slovenian and Australian bugs to one another.” Behavioral Processes 44, (July 1998): 51-58. doi:10.1016/S0376-6357(98)00030-8.

[120] Nika, Hrabar, Virant-Doberlet Meta, and Cokl Andrej. "Species specificity of male southern green stink bug Nezara viridula (L.) reactions to the female calling song." Dong wu xue bao.[Acta zoologica Sinica] 50, no. 4 (2004): 566-575.

[121] Kiritani, Keizi, Nobuhiko Hokyo, and Junichi Yukawa. "Co-Existence of the Two Related Stink bugsNezara Viridula andN. Antennata Under Natural Conditions.” Researches on Population Ecology 5, no. 1 (June 1963): 11-22. doi:10.1007/bf02518817.

[122] De Groot, M., A. Čokl, and M. Virant-Doberlet. "Effects of heterospecific and conspecific vibrational signal overlap and signalto-noise ratio on male responsiveness in Nezara viridula (L.).” Journal of Experimental Biology 213, (2010): 3213-3222. doi:10.1242/jeb.044024.

[123] De Groot, M., A. Čokl, and M. Virant-Doberlet. "Species identity cues: possibilities for errors during vibrational communication on plant stems.” Behavioral Ecology 22, (October 2011): 1209-1217. doi:10.1093/beheco/arr115.

[124] Alberto Laumann, Raul, Douglas Henrique Bottura Maccagnan, and Andrej Čokl. "Chapter 11 Use of Vibratory Signals for Stink Bug Monitoring and Control.” Stink Bugs (April 30, 2017): 226-245. doi:10.1201/9781315120713-12.

[125] Glynn Tillman, P, and Ted Cottrell. "Chapter 10 Use of Pheromones for Monitoring Phytophagous Stink Bugs (Hemiptera: Pentatomidae).” Stink Bugs (April 30, 2017): 210-225. doi:10.1201/9781315120713-11.

[126] Brownell, P., and R.D. Farley. "Orientation to vibrations in sand by nocturnal scorpions Paruroctonus mesaensis: mechanisms to target localisation.” Journal of Comparative Physiology A 131, (March 1979): 31-38. doi:10.1007/BF00613081.

[127] Hergenröder, R., and F.G. Barth. "Vibratory signals and spider behavior: How do sensory input from the eight legs interact in orientation?.” Journal of Comparative Physiology A 152, (September 1983): 361-371. doi:10.1007/BF00606241.

[128] Ota, D., and A. Čokl. "Mate location in the southern green stink bug, Nezara viridula (Heteroptera, Pentatomidae) mediated through substrate-borne signals on ivy.” Journal of Insect Behavior 4, no. 4 (Juy 1991): 441-447. doi:10.1007/BF01049329.

[129] Čokl, A., M. Virant-Doberlet, and A. McDowell. "Vibrational directionality in the southern green stink bug, Nezara viridula (L,), is mediated by female song.” Animal Behavior 58, (December 1999): 1277-1283. doi:10.1006/anbe.1999.1272.

[130] Stritih, Nataša, Meta Virant-Doberlet, and Adrej Čokl. "Green Stink Bug Nezara Viridula Detects Differences in Amplitude Between Courtship Song Vibrations at Stem and Petiolus.” Pflügers Archiv - European Journal of Physiology 439, no. 7 (July 2000): R190-R192. doi:10.1007/bf03376568.

[131] Prešern, J., J. Polajnar, M. de Groot, M. Zorović, and M. Virant-Doberlet. "On the spot: utilization of directional cues in vibrational communication of a stink bug." Scientific reports 8, (April 2018): 1-13. doi:10.1038/s41598-018-23710-x.

[132] Čokl, Andrej, Christian Otto, and Klaus Kalmring. "The Processing of Directional Vibratory Signals in the Ventral Nerve Cord ofLocusta Migratoria.” Journal of Comparative Physiology A 156, no. 1 (January 1985): 45-52. doi:10.1007/bf00610665. 